J. Product. \& Dev., 24(4): 815 - 829 (2019)

\title{
FORTIFICATION OF STIRRED YOGHURT WITH SOME MICROELEMENTS USING NATURAL SOURCES TO IMPROVE ITS NUTRITIONAL VALUE.
}

\author{
M.Y.A. El-Hawary *; Moussa, M.A.M.**, Amer, D. A. M* and Samara S. \\ Keda*1 \\ *Fac. Agric, Tanta Univ, Tanta, Egypt \\ ** Animal Pro. Res. Institute, Agric. Res. Center, Ministry of Agric, Egypt. \\ ${ }^{1}$ Samara Samir9941995@gmail.com
}

\section{ABSTRACT}

The aim of this research is to fortificate the stirred yoghurt with some microelements and natural antioxidants to improve its nutritional value. The control was stirred yoghurt made from buffalo milk. Stirred yoghurt fortified with 5\% oat and some fruits (mango, banana and strawberry jam) were prepared and their physicochemical, chemical and microbiolagical properties and some microelements ( $\mathrm{Si}, \mathrm{Fe}, \mathrm{Mn}, \mathrm{Zn}$ and $\mathrm{Cu}$ ) content of resultants products were investigated.

The data revealed that addition of oat flour slightly increase in $\mathrm{pH}$ value but these values were decreased with the addition of fruits. Also the lower in protein contents cause lower in fat while the higher in fat, fiber and carbohydrate contents were higher than control.

Mineral analyses of $\mathrm{Si}, \mathrm{Mn}$, and $\mathrm{Fe}$ contents were great difference between all treatments as they ranged between (28.7136.51) for Si, (4.61-5.26) for Mn, (3.51-4.11) for Fe and (3.31-3.61) ppm for Zn. Concerning the control, the values obtained were (14.71), (0.91), (0.71), (3.61) for $\mathrm{Si}, \mathrm{Mn}, \mathrm{Fe}$ and $\mathrm{Zn}$ respectively. The sensory evaluation showed that addition of fruits improved the total acceptability.

Conclusively, oat flour can be used as a good natural source in fortified yoghurt with micronutrients to produce yoghurt with high nutritional and functional value.

Key words: Fortification, Stirred Yoghurt, Microelements, Natural Sources, Nutritional Value. 


\section{INTRODUCTION}

Functional foods are one of the most important challenges of this country to prevent chronic diseases (Ya-Wen Zeng, el al., 2013).

Food fortification is one of the most necessary processes to improve the nutrients quantity and its quality in food. The most common method is adding micronutrients (essential trace elements, antimicrobials, vitamins and antioxidants) to food. Human body needs various micronutrients, as silicon $(\mathrm{Si})$, zinc $(\mathrm{Zn})$, manganese $(\mathrm{Mn})$ and iron $(\mathrm{Fe})$ for their functional propertion. silicon, zinc, copper and manganese are positively related to bone mass, (Jugdaohsingh, 2007). Despite their presence in small concentrations in the human body, they are playing an important role in the growth.

Silicon ( $\mathrm{Si}$ ) is the third most abundant trace element of the human body and is particularly helpful to connective tissues bone, blood vessels, hair, nails and skin. It additionally seems to lowers plasma lipids and protect from arthosclerotic (Sripnnyakorn et aL 2005). Foods derived from plants, as cereals are foods that have high levels of silicon, in contrast, foods from animal sources like meat and dairy products have low levels of silicon (Jugdaohsingh, 2007). There is limited information on the silicon concentration of foods because of difficulties related to the analytical procedures needed for silicon analysis and there is a restricted knowledge for African and Egyptian milks and their products.

Zinc $(\mathrm{Zn})$ is another mineral that has be absorbed in tiny amounts to keep humans healthy. Zinc is crucial for body growth, development and maturation tissue repair as well as resistance to illnesses. Zinc is a vital mineral for elderly and the youngsters. It can be found in poultry, meats, specifically organ meats and seafood. Though rare, a decrease in the percentage of zinc can the lower the growth in youngsters, delay wound healing in individuals of all ages, reduce resistance to infection in adults. The body requires 15.0 milligrams of zinc per day.

Iron $(\mathrm{Fe})$ is a component of the muscles and also red blood cells that help in the transportation of oxygen through the body. Iron is important in certain enzymes and the formation of hemoglobin, immune activity, several proteins and enzymes that maintain physiological state, protection against the actions of free radicals and correct functioning of the liver.

Copper $(\mathrm{Cu})$ is a very important element of the natmelanin that helps to give color for the hair, skin, and eyes. The use of copper supplements helps in protection against graying of the hair. Thus whereas it is usually overlooked as 
an antioxidant mineral, it will defend the integrity of those cells and keeps you trying young. It also maintains the color of your eyes and is crucial, together with zinc, to keep your eyes fantastically colored into your adulthood. Copper deficiency is rare, but can occur in people who have chronic diarrhea or who are severely under nourished.

Manganese $(\mathrm{Mn})$ is a trace mineral that is important to life. The human body contains about 15 to 20 milligrams of it. Adults need solely concerning about $2 \mathrm{mg}$ manganese per day. Most of it is found in the bones, with the rest distributed throughout the body in tissues just like the kidneys, liver, pancreas, pituitary glands and adrenal glands.

Unfortunately, Milk and dairy products have a poor content of these elements and there is no enough information about a private in the African and Egyptian food. On the opposite, most people in underdeveloped or developing countries suffer from micronutrients deficiency and enriched food merchandise can dramatically cut back the nutritional diseases. Therefore, the consumption of fortified food is demanding. Because of the high consumption rate of dairy products like yogurt, fortification of these products will effectively prevent or reduce diseases related to nutritional deficiencies.

One of the most important functional foods widely consumed is yoghurt because of its bioavailability, high digestibility and proteolytic activities. The market currently offers a vast array of yoghurt to suit all palates and meal occasions. They are available in a very type of fat contents (e.g. luxury, low-fat, virtually fat-free), flavors (e.g. natural, fruit, cereal) and textures (e.g. liquid, set, smooth), can be consumed as a part of a meal or a snack or as savory food or a sweet and are available all yearround (Dairy Council, 2016).

Many studies on supplementation of yoghurt with dietary fiber (Damian and Olteanu, 2014), micronutrients (Sazawal et al., 2013), and omega-3 polyunsaturated fatty acids (McCowen et al., 2010) were carried out, but studies on fortification with microelements still limited as oat is a rich source of microelements and soluble non digestible fiber. It contains high level of silicon as well as iron and manganese (Ahmad et at., 2014).

Therefore, the aim of this study to improvement the natural value and healthy benefits of final product. 


\section{MATERIALS AND METHODS}

Buffalo milk: was obtained from Mahalat Moussa station, the starter: of streptococccus thermophilus and lactobacillus bulgaricus were from Chr. Hansen were obtained from the Unit of Milk Industry, Animal production research Institute, The oat flour: The rolled oats (Avena sativa) was obtained from local market and The fruits including: Mango (Mangiferaindica L.): Mango Sukari cultivar and banana as well as Strawberry (Fragaria ananassa) jam were purchased from the local market.

Fruits preparation: fresh fruits were washed and allowed to dry at room temperature.

Yoghurt treatments with oat flour were carried out to reach the suitable proportions of oat flour $(2.5,5$, and $7.5 \%)$ to be used for making oat yoghurt. According to the most palatable taste the protein $5 \%$ was the best natural yoghurt (the control) was prepared from fresh skim milk mixed with 5\% skim milk powder to increase total solids in the final milk mixture was blended. For yoghurt with oat treatment, fresh skim milk was mixed with 5\% oat flour as a substitute to skim milk powder (T1).

The mixture was heated at $85_{\mathrm{o}} \mathrm{c}$ for $10 \mathrm{~min}$. and then rapidly cooled to 45 oc, the activated starter was added at a rate $3 \%$. At this point, the yoghurt was left overnight in a refrigerator. The yoghurt coagulum was broken manually by means of a perforated stirrer, by stirring the coagulum twenty five times in slow helicoidally movements. This was done in order to insure that the yoghurt coagulum was completely broken and that whey incorporation was promoted. After this operation, the stirred yoghurt was circulated through the plate heat exchanger where it was cooled down by the cold water stream. Then the samples of $100 \mathrm{~g}$ stirred yoghurt were filled into plastic cups and stored in the refrigerator $(5 c)$ for 15 days. Treatments of oats yoghurt with fruits:

$\mathbf{T}_{2}: 85 \mathrm{~g}$ stirred yoghurt with oats $+15 \mathrm{~g}$ mashed mango pulp

$\mathbf{T}_{3}$ : $85 \mathrm{~g}$ stirred yoghurt with oats $+15 \mathrm{~g}$ mashed banana pulp

$\mathbf{T}_{4}: 85 \mathrm{~g}$ stirred yoghurt with oats $+15 \mathrm{~g}$ strawberry jam

Chemical analysis of milk sample and stirred yoghurt treatments were determined for total solids, protein, ash and crude fiber according to A.O.A.C (2012).

$\mathrm{pH}$ values were determined using a digital $\mathrm{pH}$ meter (Jenway $3505 \mathrm{pH}$ meter). Carbohydrate content of all samples was determined as a calculation.

Fat was determined by Gerber method for milk and cheese samples, while Fat of oat flour, fruits and all stirred yoghurt treatments was analyzed 
by using Soxhlet method. Fat content was analyzed according to Ling (1963).

Protein content of all samples was determined by using micro Kjeldahl methods. AOAC (2012).

Microbiological analysis: Total bacterial count and mould and yeast contents of stirred yoghurt were determined according to the method described by the AOAC (2012).

Determinations of micro and macro elements were carried out by using Agilent microwave plasma atomic emission spectrometry.

Silicon was determined in milk and stirred yoghurt treatments. Also other micro elements $(\mathrm{Mn}, \mathrm{Fe}, \mathrm{Zn}$ and $\mathrm{Cu}$ ) were determined for stirred yoghurt treatments, as well as macro elements ( $\mathrm{Ca}, \mathrm{P}, \mathrm{Mg}$ and $\mathrm{K}$ ).

\section{Sensory evaluations:}

The sensory assessment was performed on natural stirred yoghurt and enriched stirred yoghurt prepared in fresh and during storage. The sensory panelists rated the stirred yogurt for flavor (50), body and texture, (35), appearance (15) and overall acceptability (100) according to Shahani et al., (1979).

\section{Statistical Analysis:}

Sample were assayed results are given as mean + SD. The statistical analysis was carried out according to Steel et al., (1980) on the results obtained from biological experiments.

Statistical significance for data was determined using a one-way analysis of variance (ANOVA) and Duncan's Multiple Range test as well as Standard Error carried out using a SAS computer program (SAS,1987).

\section{RESULTS AND DISCUSSION}

\section{Chemical composition of materials used in fortified stirred yoghurt}

The chemical composition of oat flour, mango, banana pulps and strawberry jam which used for fortification of stirred yoghurt is recorded in Table 1. The results showed that oats contained high total solids $(91.71 \%)$, protein $(11.03 \%)$, fat $(6.77 \%)$, carbohydrate $(57.97 \%)$ and ash $(5.95 \%)$. Also, it characterized by high fiber content (10.01\%). Analysis of Fruits (mango and banana) and strawberry jam demonstrated that those had high percentages in fiber content with maximum value in mango. 
Table (1). Chemical composition of oats and fruits

\begin{tabular}{|l|c|c|c|c|}
\hline $\begin{array}{c}\text { Composition } \\
(\%)\end{array}$ & $\begin{array}{c}\text { Oat } \\
\text { Flour }\end{array}$ & $\begin{array}{c}\text { Mango } \\
\text { Pulp }\end{array}$ & $\begin{array}{c}\text { Banana } \\
\text { Pulp }\end{array}$ & $\begin{array}{c}\text { Strawberry } \\
\text { Jam }\end{array}$ \\
\hline Total solids & 91.71 & 28.71 & 24.44 & 69.10 \\
\hline Protein & 11.03 & 1.83 & 1.11 & 1.35 \\
\hline Fat & 6.77 & 0.83 & 0.33 & 0.72 \\
\hline Ash & 5.95 & 1.83 & 1.11 & 0.95 \\
\hline Fiber & 10.01 & 7.01 & 2.57 & 3.93 \\
\hline Carbohydrate & 57.97 & 17.45 & 19.36 & 62.19 \\
\hline
\end{tabular}

The high percentages in carbohydrate content and low in fat and protein were observed in fruits pulps and strawberry jam as was expected.

Table (2) showed $\mathrm{pH}$ values and the chemical composition of fortified stirred yoghurt treatments. It can be seen that $\mathrm{pH}$ value was increase with oats treatment and gradually decrease with fruit treatments.

Table (2). Chemical composition of fortified stirred yoghurt

\begin{tabular}{|c|c|c|c|c|c|}
\hline \multirow{2}{*}{ Composition } & \multicolumn{5}{|c|}{ Treatment groups } \\
\cline { 2 - 6 } & Control & $\mathbf{T}_{\mathbf{1}}$ & $\mathbf{T}_{\mathbf{2}}$ & $\mathbf{T}_{\mathbf{3}}$ & $\mathbf{T}_{\mathbf{4}}$ \\
\hline \multirow{2}{*}{ Ph value } & 4.47 & 4.58 & 4.46 & 4.47 & 4.23 \\
& $\pm 0.01^{\mathrm{ab}}$ & $\pm 0.02^{\mathrm{a}}$ & $\pm 0.03^{\mathrm{b}}$ & $\pm 0.01^{\mathrm{b}}$ & $\pm 0.01^{\mathrm{c}}$ \\
\hline T.S, \% & 13.02 & 12.81 & 15.16 & 14.56 & 21.24 \\
& $\pm 0.01^{\mathrm{c}}$ & $\pm 0.01^{\mathrm{d}}$ & $\pm 0.02^{\mathrm{ab}}$ & $\pm 0.01^{\mathrm{b}}$ & $\pm 0.02^{\mathrm{a}}$ \\
\hline Protein, \% & 5.43 & 4.12 & 4.01 & 3.81 & 3.86 \\
& $\pm 0.05^{\mathrm{a}}$ & $\pm 0.01^{\mathrm{ab}}$ & $\pm 0.01^{\mathrm{b}}$ & $\pm 0.05^{\mathrm{bc}}$ & $\pm 0.03^{\mathrm{c}}$ \\
\hline Fat, \% & 0.16 & 0.44 & 0.50 & 0.43 & 0.47 \\
& $\pm 0.02^{\mathrm{d}}$ & $\pm 0.01^{\mathrm{b}}$ & $\pm 0.01^{\mathrm{a}}$ & $\pm 0.03^{\mathrm{bc}}$ & $\pm 0.02^{\mathrm{ab}}$ \\
\hline Ash, \% & 1.09 & 1.04 & 1.13 & 1.06 & 1.03 \\
& $\pm 0.02^{\mathrm{ab}}$ & $\pm 0.01^{\mathrm{bc}}$ & $\pm 0.01^{\mathrm{a}}$ & $\pm 0.03^{\mathrm{b}}$ & $\pm 0.02^{\mathrm{c}}$ \\
\hline Fiber, \% & - & 0.60 & 0.99 & 0.84 & 1.02 \\
& & $\pm 0.01^{\mathrm{d}}$ & $\pm 0.02^{\mathrm{ab}}$ & $\pm 0.03^{\mathrm{b}}$ & $\pm 0.01^{\mathrm{a}}$ \\
\hline Carbohy., \% & 6.27 & 6.64 & 8.57 & 8.45 & 14.90 \\
& $\pm 0.02^{\mathrm{d}}$ & $\pm 0.01^{\mathrm{c}}$ & $\pm 0.02^{\mathrm{b}}$ & $\pm 0.02^{\mathrm{bc}}$ & $\pm 0.01^{\mathrm{a}}$ \\
\hline Significant test & $*$ & $*$ & $*$ & $*$ & $*$ \\
\hline
\end{tabular}

(a.b, ...d) Means at the row with different superscripts are different $(\mathrm{P}<0.05)$ by Duncan's multiple comparison tests

Control: Stirred yoghurt without any addition; $\mathbf{T}_{\mathbf{1}}$ : Stirred yoghurt with oat flour; $\mathbf{T}_{\mathbf{2}}$ : Stirred yoghurt with oat flour + mango $; \mathbf{T}_{\mathbf{3}}$ : Stirred yoghurt with oat flour + banana $-\mathbf{T}_{\mathbf{4}}$ : Stirred yoghurt with oat flour + Strawberry Jam.

$* \mathrm{P}<0.05$ 
This decrease may be due to the citric acid content in fruits (Gahruie et al., 2015). Moreover all yoghurt treatments decreased in PH values during storage as shown in Table (3).

The rate of decreasing $\mathrm{pH}$ for all fortified treatments was lowest compared with control. It was found the total solid of treatment of oats was $12.81 \%$ closed to control and increase in ranged from 14.56 to $21.24 \%$ with fruits addition as shown in Table (2).

Table (3). Change of $\mathrm{pH}$ values of fortified stirred yoghurt during storage

\begin{tabular}{|c|c|c|c|c|c|}
\hline \multirow{2}{*}{$\begin{array}{c}\text { Storage } \\
\text { (day) }\end{array}$} & \multicolumn{5}{|c|}{ Treatment groups } \\
\cline { 2 - 6 } Fresh & Control & $\mathbf{T}_{\mathbf{1}}$ & $\mathbf{T}_{\mathbf{2}}$ & $\mathbf{T}_{\mathbf{3}}$ & $\mathbf{T}_{\mathbf{4}}$ \\
& 4.49 & 4.57 & 4.46 & 4.47 & 4.23 \\
& $\pm 0.01^{\mathrm{Aa}}$ & $\pm 0.02^{\mathrm{Aa}}$ & $\pm 0.03^{\mathrm{Aa}}$ & $\pm 0.01^{\mathrm{Aa}}$ & $\pm 0.01^{\mathrm{Aa}}$ \\
\hline $\mathbf{3}$ & 4.41 & 4.51 & 4.41 & 4.43 & 4.22 \\
& $\pm 0.02^{\mathrm{Ab}}$ & $\pm 0.03^{\mathrm{Ab}}$ & $\pm 0.03^{\mathrm{Ab}}$ & $\pm 0.01^{\mathrm{Ab}}$ & $\pm 0.03^{\mathrm{Ab}}$ \\
\hline $\mathbf{7}$ & 4.37 & 4.47 & 4.35 & 4.39 & 4.19 \\
& $\pm 0.01^{\mathrm{Cc}}$ & $\pm 0.01^{\mathrm{Bc}}$ & $\pm 0.02^{\mathrm{Bc}}$ & $\pm 0.01^{\mathrm{Ac}}$ & $\pm 0.02^{\mathrm{Ac}}$ \\
\hline $\mathbf{1 0}$ & $4.31^{\mathrm{Cd}}$ & 4.43 & 4.29 & 4.34 & 4.12 \\
& $\pm 0.03^{\mathrm{Cd}}$ & $\pm 0.01^{\mathrm{Bb}}$ & $\pm 0.01^{\mathrm{Bd}}$ & $\pm 0.01^{\mathrm{Bc}}$ & $\pm 0.03^{\mathrm{Bc}}$ \\
\hline $\mathbf{1 5}$ & 4.25 & 4.41 & 4.18 & 4.23 & 4.05 \\
& $\pm 0.01^{\mathrm{Dd}}$ & $\pm 0.02^{\mathrm{Cd}}$ & $\pm 0.01^{\mathrm{Cd}}$ & $\pm 0.03^{\mathrm{Cd}}$ & $\pm 0.02^{\mathrm{Cd}}$ \\
\hline Significant test & $*$ & $*$ & $*$ & $*$ & $*$ \\
\hline
\end{tabular}

$(a . b, \ldots d)$ Means at the row with different superscripts are different $(\mathrm{P}<0.05)$ by Duncan's multiple comparison test.

(A.B, ...D) Means at the column with different superscripts are different $(\mathrm{P}<0.05)$ by Duncan's tests multiple comparison tests.

Control: Stirred yoghurt without any addition; $\mathbf{T}_{\mathbf{1}}$ : Stirred yoghurt with oat flour; $\mathbf{T}_{\mathbf{2}}$ : Stirred yoghurt with oat flour + mango $; \mathbf{T}_{3}$ :Stirred yoghurt with oat flour + banana $-\mathbf{T}_{\mathbf{4}}$ : Stirred yoghurt with oat flour + Strawberry Jam. (A.B) Means at the column with different superscripts are different $(\mathrm{P}<0.05)$ by Duncan's tests multiple comparison tests.

$* \mathrm{P}<0.05$.

These increases due to high content of total solids in fruits as shown in Table 1. Also, data in Table (4) revealed that total solid in both control and all treatments increased during storage period. Protein content and ash slightly decrease with oats treatments. While, the total carbohydrate increased with all oats treatments. Also, the increase in fat content of oats treatments was observed. This due to the fat content of oats was $6.77 \%$ (Table 1 ).

According to reported data of Sterna et al, (2015), the lipid content in the oat ranged from 5.20 to $12.40 \%$. Fiber content found in the oats treatments $(0.50 \%)$ and increased in range $0.82-1.01 \%$ with fruits Treatments. 
Table (4). Change of total solids in fortified stirred yoghurt during storage

\begin{tabular}{|c|c|c|c|c|c|}
\hline \multirow{2}{*}{$\begin{array}{c}\text { Storage } \\
\text { (day) }\end{array}$} & \multicolumn{5}{|c|}{ Treatment groups } \\
\hline & Control & $\mathbf{T}_{1}$ & $\mathbf{T}_{2}$ & $\mathbf{T}_{3}$ & $\mathbf{T}_{4}$ \\
\hline Fresh & $\begin{array}{c}13.02 \\
\pm 0.01^{\mathrm{Dd}}\end{array}$ & $\begin{array}{l}12.81 \\
\pm 0.01^{\mathrm{Dc}}\end{array}$ & $\begin{array}{c}15.19 \\
\pm 0.02^{\mathrm{Bc}}\end{array}$ & $\begin{array}{c}14.56 \\
\pm 0.01^{\mathrm{Cb}}\end{array}$ & $\begin{array}{c}21.24 \\
\pm 0.01^{\mathrm{Ab}}\end{array}$ \\
\hline 3 & $\begin{array}{c}13.06 \\
\pm 0.02^{\mathrm{Dc}}\end{array}$ & $\begin{array}{l}12.86 \\
\pm 0.02^{\mathrm{Db}}\end{array}$ & $\begin{array}{c}15.21 \\
\pm 0.03^{\mathrm{Bc}}\end{array}$ & $\begin{array}{c}14.61 \\
\pm 0.02^{\mathrm{Cb}}\end{array}$ & $\begin{array}{c}21.26 \\
\pm 0.01^{\mathrm{Ab}}\end{array}$ \\
\hline 7 & $\begin{array}{c}13.2 \\
\pm 0.01^{\mathrm{Db}}\end{array}$ & $\begin{array}{l}12.89 \\
\pm 0.01^{\mathrm{Db}}\end{array}$ & $\begin{array}{c}15.23 \\
\pm 0.01^{\mathrm{Bb}}\end{array}$ & $\begin{array}{c}14.64 \\
\pm 0.03^{\mathrm{Ca}}\end{array}$ & $\begin{array}{c}21.31 \\
\pm 0.04^{\mathrm{Aa}}\end{array}$ \\
\hline 10 & $\begin{array}{c}13.13 \\
\pm 0.03^{\mathrm{Ca}}\end{array}$ & $\begin{array}{l}12.92 \\
\pm 0.04^{\mathrm{Da}}\end{array}$ & $\begin{array}{c}15.26 \\
\pm 0.02^{\mathrm{Ba}}\end{array}$ & $\begin{array}{c}14.65 \\
\pm 0.02^{\mathrm{Ca}}\end{array}$ & $\begin{array}{c}21.33 \\
\pm 0.02^{\mathrm{Aa}}\end{array}$ \\
\hline 15 & $\begin{array}{c}13.15 \\
\pm 0.02^{\mathrm{Ca}}\end{array}$ & $\begin{array}{l}12.98 \\
\pm 0.03^{\mathrm{Da}}\end{array}$ & $\begin{array}{c}15.31 \\
\pm 0.04^{\mathrm{Ba}}\end{array}$ & $\begin{array}{c}14.71 \\
\pm 0.01^{\mathrm{Ba}}\end{array}$ & $\begin{array}{c}21.36 \\
\pm 0.02^{\mathrm{Aa}}\end{array}$ \\
\hline Significant test & $*$ & $*$ & $*$ & $*$ & $*$ \\
\hline
\end{tabular}

a.b, c) Means at the row with different superscripts are different $(P<0.05)$ by Duncan's multiple comparison tests.

(A.B, ...D) Means at the column with different superscripts are different $(\mathrm{P}<0.05)$ by Duncan's tests multiple comparison tests.

Control: Stirred yoghurt without any addition; $\mathbf{T}_{1}$ : Stirred yoghurt with oat flour; $\mathbf{T}_{2}$ : Stirred yoghurt with oat flour + mango $; \mathbf{T}_{3}:$ Stirred yoghurt with oat flour + banana $-\mathbf{T}_{\mathbf{4}}$ : Stirred yoghurt with oat flour + Strawberry Jam.

$* \mathrm{P}<0.05$.

These results attributed to high content fiber in oats and fruits as shown in Table (1), which were in line with the previous studies (Forster et al., 2003; Ahmad et al., 2014).

Table (5) illustrated that, the total bacterial counts; molds and yeasts counts in fortified stirred yoghurt were the lowest compared with control when fresh. Also, data showed that the decreasing numbers of total bacterial counts were in fortified stirred yoghurt with oat flour $\left(\mathrm{T}_{1}\right)$, treatment of strawberry $\left(\mathrm{T}_{4}\right)$ and control after 7 days of storage, and then started to increase till 15 days.

This may be due to the sensitivity of microorganisms to the produced acidity, but there was clear increase in total bacterial counts of banana $\left(\mathrm{T}_{3}\right)$ and strawberry treatments $\left(\mathrm{T}_{4}\right)$ after 7 and 15 days of storage period. 
Table (5). Growth of Total bacterial counts and yeast and molds in fortified stirred yoghurt during storage period.

\begin{tabular}{|c|c|c|c|c|c|c|}
\hline \multirow{3}{*}{ Treatments } & \multicolumn{6}{|c|}{ Storage period (days) } \\
\hline & \multicolumn{2}{|c|}{ Fresh } & \multicolumn{2}{|c|}{7 days } & \multicolumn{2}{|c|}{15 days } \\
\hline & $\begin{array}{c}\text { T.C } \\
10^{6} \\
\text { CFU/g }\end{array}$ & $\begin{array}{c}\mathrm{M \& Y} \\
10^{2} \\
\mathrm{CFU} / \mathrm{g} \\
\end{array}$ & $\begin{array}{c}\text { T.C } \\
10^{6} \\
\text { CFU/g }\end{array}$ & $\begin{array}{c}\text { M\&Y } \\
10^{2} \\
\text { CFU/g }\end{array}$ & $\begin{array}{c}\text { T.C } \\
10^{6} \\
\text { CFU/g }\end{array}$ & $\begin{array}{c}\text { M\&Y } \\
10^{2} \\
\text { CFU/g }\end{array}$ \\
\hline Control & 1.201 & N.D & 1.41 & 5 & 5.29 & 2 \\
\hline $\mathbf{T}_{1}$ & 3.61 & N.D & 3.01 & 12 & 4.65 & 37 \\
\hline $\mathbf{T}_{2}$ & 5.1 & N.D & 1.25 & 2 & 3.21 & 65 \\
\hline $\mathbf{T}_{\mathbf{3}}$ & 1.21 & N.D & 3.61 & 3 & 3.45 & 81 \\
\hline $\mathbf{T}_{4}$ & 3.41 & N.D & 2.49 & N.D & 2.65 & 15 \\
\hline
\end{tabular}

Control: Stirred yoghurt without any addition; $\mathbf{T}_{1:}$ Stirred yoghurt with oat flour; $\mathbf{T}_{2}$ : Stirred yoghurt with oat flour $+\operatorname{mango} ; \mathbf{T}_{3}:$ Stirred yoghurt with oat flour + banana $-\mathbf{T}_{4}:$ Stirred yoghurt with oat flour + Strawberry Jam.

N.D: Not detected, M\&Y: Molds and yeasts, T.C: Total bacterial Counts, CFU:

Colony forming unit

\section{Some microelements contents in fortified stirred yogurt:}

Microelements including silicon, iron, manganese, zinc and copper contents in stirred yoghurt treatments are presented in Tables (6 and 7). Silicon levels in stirred yoghurt (control) and oat treatment were $14.71 \pm$ 0.11 and $23.23 \pm 0.08 \mathrm{ppm}$ respectively. These results indicated that oat increased silicon content by $59 \%$ in stirred yogurt. These results indicated that oat was a good natural source for silicon. Oat as grain contains high level of silicon as reported by Powell et al., (2005).

Concerning to the treatments of oat flour with fruits, data showed that the maximum level of silicon was found in banana and mango treatments. This is due to fortification with mango and banana fruits which contain high concentration of silicon concentration as reported by Powell et al., (2005). Previous work showed that banana has higher Si content, in contrast to the majority of other fruits, however, silicon uptake from banana was low (Jugdaohsingh et al., 2002). 
Table ( 6). Microelements concentrations of fortified stirred yoghurt

\begin{tabular}{|l|c|c|c|c|c|}
\hline \multirow{2}{*}{$\begin{array}{l}\text { Treatment } \\
\text { groups }\end{array}$} & \multicolumn{5}{|c|}{ Concentrations of microelements ppm } \\
\cline { 2 - 6 } Control & 14.71 & $\mathbf{M n}$ & $\mathbf{F e}$ & $\mathbf{Z n}$ & $\mathbf{C u}$ \\
& $\pm 0.11^{\mathrm{d}}$ & $\pm 0.05^{\mathrm{b}}$ & $\pm 0.01^{\mathrm{d}}$ & $\begin{array}{c}3.61 \\
\pm 0.04^{\mathrm{ab}}\end{array}$ & N.D* \\
\hline $\mathbf{T}_{\mathbf{1}}$ & 23.23 & 4.91 & 3.91 & 3.62 & N.D \\
& $\pm 0.08^{\mathrm{c}}$ & $\pm 0.02^{\mathrm{b}}$ & $\pm 0.01^{\mathrm{b}}$ & $\pm 0.02^{\mathrm{a}}$ & \\
\hline $\mathbf{T}_{\mathbf{2}}$ & 35.41 & 4.61 & 4.11 & 3.43 & N.D \\
& $\pm 0.02^{\mathrm{ab}}$ & $\pm 0.03^{\mathrm{c}}$ & $\pm 0.01^{\mathrm{a}}$ & $\pm 0.03^{\mathrm{bc}}$ & \\
\hline $\mathbf{T}_{\mathbf{3}}$ & 36.51 & 4.66 & 4.04 & 3.3 & N.D \\
& $\pm 0.05^{\mathrm{a}}$ & $\pm 0.04^{\mathrm{bc}}$ & $\pm 0.02^{\mathrm{ab}}$ & $\pm 0.04^{\mathrm{c}}$ & \\
\hline $\mathbf{T}_{\mathbf{4}}$ & 28.71 & 5.26 & 3.51 & 3.51 & N.D \\
& $\pm 0.07^{\mathrm{b}}$ & $\pm 0.01^{\mathrm{a}}$ & $\pm 0.01^{\mathrm{a}}$ & $\pm 0.10^{\mathrm{b}}$ & \\
\hline Significant test & $*$ & $*$ & $*$ & $*$ & $*$ \\
\hline
\end{tabular}

$(a . b, \ldots)$ Means at the row with different superscripts are different $(\mathrm{P}<0.05)$ by Duncan's multiple comparison tests

Control: Stirred yoghurt without any addition; $\mathbf{T}_{\mathbf{1}}$ : Stirred yoghurt with oat flour; $\mathbf{T}_{2}$ : Stirred yoghurt with oat flour + mango $; \mathbf{T}_{3}:$ Stirred yoghurt with oat flour + banana $-\mathbf{T}_{\mathbf{4}}:$ Stirred yoghurt with oat flour + Strawberry Jam.

N.D: Not detected.

$* \mathrm{P}<0.05$..

Table (7). Some macro elements concentrations of fortified stirred yoghurt

\begin{tabular}{|c|c|c|c|c|}
\hline \multirow{2}{*}{ Treatments } & \multicolumn{4}{|c|}{ Concentration of macro elements ppm } \\
\cline { 2 - 5 } Control & $1705 \pm 10^{\mathrm{a}}$ & $1138 \pm 12^{\mathrm{a}}$ & $2258 \pm 14^{\mathrm{a}}$ & $219 \pm 3^{\mathrm{cd}}$ \\
\hline $\mathbf{T}_{\mathbf{1}}$ & $1567 \pm 11^{\mathrm{b}}$ & $911 \pm 8^{\mathrm{c}}$ & $1619 \pm 15^{\mathrm{d}}$ & $220 \pm 2^{\mathrm{c}}$ \\
\hline $\mathbf{T}_{\mathbf{2}}$ & $1454 \pm 9^{\mathrm{c}}$ & $924 \pm 5^{\mathrm{b}}$ & $1629 \pm 11^{\mathrm{c}}$ & $223 \pm 3 \mathrm{~b}$ \\
\hline $\mathbf{T}_{\mathbf{3}}$ & $1359 \pm 5^{\mathrm{d}}$ & $802 \pm 4^{\mathrm{d}}$ & $2075 \pm 12^{\mathrm{b}}$ & $228 \pm 4^{\mathrm{a}}$ \\
\hline $\mathbf{T}_{\mathbf{4}}$ & $1154 \pm 7^{\mathrm{e}}$ & $720 \pm 5^{\mathrm{e}}$ & $1615 \pm 11^{\mathrm{e}}$ & $193 \pm 3^{\mathrm{d}}$ \\
\hline Significant test & $*$ & $*$ & $*$ & $*$ \\
\hline
\end{tabular}

a.b) Means at the row with different superscripts are different $(\mathrm{P}<0.05)$ by Duncan's multiple comparison tests

Control: Stirred yoghurt without any addition; $\mathbf{T}_{\mathbf{1}}$ : Stirred yoghurt with oat flour; $\mathbf{T}_{\mathbf{2}}$ : Stirred yoghurt with oat flour + mango $; \mathbf{T}_{3}$ :Stirred yoghurt with oat flour + banana $-\mathbf{T}_{\mathbf{4}}$ : Stirred yoghurt with oat flour + Strawberry Jam.

$* \mathrm{P}<0.05$. 
The results showed high variations in manganese levels between fortified yoghurt treatments and control. The manganese level in control was $0.91 \pm 0.05 \mathrm{ppm}$ and elevated to $4.91 \pm 0.02 \mathrm{ppm}$ a affected by oats addition. From the results, it was found that the concentration of manganese was in range $4.61 \pm 0.03$ and $5.26 \pm 0.01 \mathrm{ppm}$ in oats with fruits treatments, with maximum value in strawberry treatment followed by banana and mango treatments. Manganese and silicon are necessary for bone health (Jugdaohsingh, 2007).

With regard to iron content, results should higher increase in iron content of fortified stirred yoghurt with oat $(3.91 \pm 0.01 \mathrm{ppm})$ compared with control $(0.71 \pm 0.05 \mathrm{ppm})$.

Also, the iron content in oat and fruits treatments was observed in range of $3.51 \pm 0.01$ to $4.11 \pm 0.01 \mathrm{ppm}$. Dairy products are poor in iron content (Gahruie et al., 2015).While; iron-fortified yogurt has relatively high iron bioavailability (Woestyne et al., 1991).

Concerning zinc element, the result indicated no variations in $\mathrm{Zn}$ content between fortified stirred yoghurt treatments and control.

Zinc element is necessary in cellular replication and the development of the immune response. Copper was not detected in all treatments.

\section{Sensory evaluation:}

The sensory properties of the stirred yoghurt were evaluated by panelists and the results are summarized in Table 8 .

Table (8). Sensory evaluation of fortified stirred yoghurt

\begin{tabular}{|c|c|c|c|c|}
\hline Treatments & $\begin{array}{c}\text { Flavor } \\
(\mathbf{5 0})\end{array}$ & $\begin{array}{c}\text { Body \& } \\
\text { Texture (35) }\end{array}$ & $\begin{array}{c}\text { Appearance } \\
(\mathbf{1 5})\end{array}$ & $\begin{array}{c}\text { Total } \\
(\mathbf{1 0 0})\end{array}$ \\
\hline Control & 46 & 35 & 14 & 95 \\
\hline $\mathbf{T}_{\mathbf{1}}$ & 44 & 34 & 13 & 91 \\
\hline $\mathbf{T}_{\mathbf{2}}$ & 49 & 35 & 14 & 98 \\
\hline $\mathbf{T}_{\mathbf{3}}$ & 46 & 35 & 12 & 93 \\
\hline $\mathbf{T}_{\mathbf{4}}$ & 49 & 35 & 14 & 98 \\
\hline
\end{tabular}

Control: Stirred yoghurt without any addition; $\mathbf{T}_{\mathbf{1}}$ : Stirred yoghurt with oat flour; $\mathbf{T}_{2}$ : Stirred yoghurt with oat flour + mango $; \mathbf{T}_{3}$ :Stirred yoghurt with oat flour + banana $-\mathbf{T}_{\mathbf{4}}$ : Stirred yoghurt with oat flour + Strawberry Jam. 
The fortified yoghurt with oat at concentration of $5 \%$ had flavor score (44), which were lower than that for control (46). Whereas the flavor scores of fruits containing fortified yoghurt with oat and fruits ranged from $46-49$, indicating that the fruits improved the flavor of fortified yoghurt with oat.

High total scores were received by mango pulp and strawberry jam containing yoghurt. Moreover, the overall acceptability increased with addition of fruits. Therefore, the addition of fruits in fortified stirred yoghurt with oat flour improved the sensory characteristics of end product.

Conclusively, Oat flour can be used as a good natural source in fortified yoghurt with micronutrients to produce yoghurt with high nutritional and functional value.

\section{REFERENCES}

Ahmad,M.; Gul-Zaffar, Z. A.Dar and Habib, M.(2014). Areview on Oat (Avena sativa L.) as a dual-purpose crop. Academic Journal, $9,(4): 52-59$.

AOAC (2012).Association of Official Analytical Chemists.Official Methods of Analysis $19^{\text {th }}$ Ed., Washington ,D. C, USA.

Dairy Council. (2016) - Email: info @ dairy council. Org. uk-Web: www.milk .com. uk.

Damian ,C.and Olteanu , A. (2014) . Influence of dietary fiberfrom pea on some quality characteristics of yoghurts. Journal Of Agro Alimentray Processes And Technologies , 20, (2) : 156-160.

Forster, M.; Rodriguezl, E. R. ; Martin, J. D. and Diaz Romero, C.(2003). Distribution of Nutrients in Edible Banana Pulp. Food Technol .Biotechnol., 41( 2):167-171.

Gahruie H.H.; Eskandari, M.H.; Mesbahi , G. and Hanifpour, M.A. (2015). Scientific and technical aspects of yoghurt fortification . Food Science and Human Wellness, 4, 1-8.

Juhgdaohsing , R .; Anderson, S.H . C.; Tucker , K.L.; Elliott, H. Kiel, D.P.; Thompson , R.P.H . and Powell, J.J. (2002).Dietary silicon intake and absorption. Am. Journal of Clin. Nutr.,75:887893.

Juhdaohsingh , R . (2007) .Silicon and bone health. Journal of Nutr. Health Aging, 11 (2): 99-110 . 
Ling, E.R. (1963). A Textbook of Dairy Chemistry. Vol. 11, Practical, 3rd Ed., Chapman and Hall, London, UK.

McCowen , K . C.; MRCPII, M.D.; Ling, P.M.; Decker, EDjordjevic , D.; Roberts , R.F .; Couplavd, J.N .and Bistrian ., B.R. M.D (2010). A simple Method of Supplementation of Omega-3 polyunsaturated Fatty Acids : Use of Fortified Yoghurt in Healthy Volunteers. Nutrition in Clinical practice, 25 (6): $641-645$.

Powell, J.J.; McNaughton , S.A; Juhdaohsingh , R.; Anderson Dear , J.; Khor, F. ; Mowatt, L; Gleason, K.L.; Sykes , Thompson , R.P.H ; Bolton - Smith , C. and Hodson , M.G.(2005) . A provisional database for the silicon content of food in the United Kingdom. British Journal Nutrition, 94: 804- 812.

Sazawal.S.;Habib, A.A. Dhingra, U.; Dutta, A.; Dhingra, P.; Sarkar,A.; Deb, S.; Alam, J. Husna , A. and Black , R. E.( 2013). Impact of micronutrient fortication of yoghurt onmicronutrients status markers and growth: A randomized double blind controlled trial among school children in Bangladesh. Public Health, 13: 514 .

SAS (1987). Statistical Analysis System. User`s guide, version 6 ed., SAS Institute, Cary. N. C., USA.

Shahani, K, M, and R, C, Chandan (1979). Nutritional and healthful aspects of cultured and Culture containing dairy foods. J. Dairy Sci.,62

Sripanyakorn, S.; Jugdaohsingh, R.; Thompson, R. P. H. and Powell, J. J. (2005). Dietary silicon and bone health. British Nutrition Foundation Nutrition Bulletin, 30: 222-230.

Steel, R. G. and J. H. Torrie (1980): Principles And Procedures Of Statistical Megrim. - Hill Book Co., New York, NY.

Sterna, V.; Zute, S.; Jansone, I; L.and Kantane, I. (2015). The Chemical Composition of New Oat Varieties and Breeding Lines Created in Latvia. Acta.Biol.Univ.Daugavp., 15(2):367-373.

Woestyne, M. W.; Brownell, B.; Mergeay, M. and Verstraete, W.(1991). The Fe 2+ chelatorproferrorosamine A is essential for the siderophore mediated uptake of iron by pseudo moasroseus fluorescences. Appl. Environ. Microbiol, 57: 949 - 954. 
Ya-Wen Zeng; Jia-Zheng Yang; Xiao- Ying Pu; Juan Du; Tao Yang ; Shu- Ming yang and Wei - Hua Zhu. (2013). Strategies of functional food cancer prevention, in human beings. Asian Pacific. Journal of Cancer Prevention, 14n:1585- 1592

\section{تلديم الزبادي المقلب ببعض العناصر الصغري

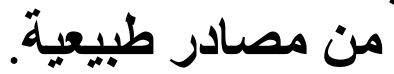

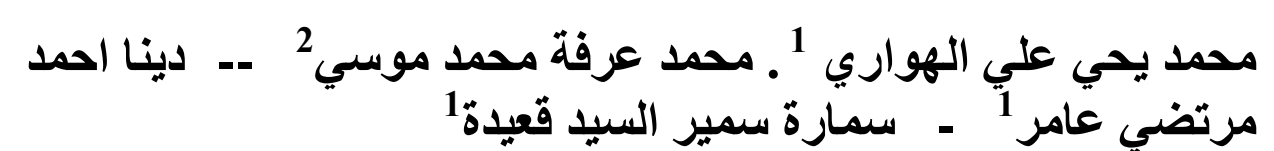

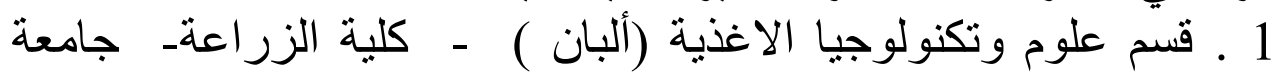

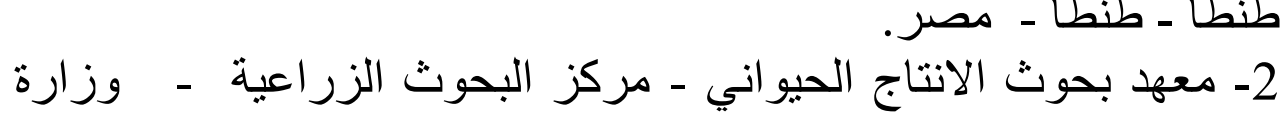

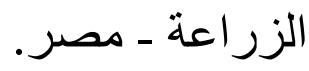

تم تصنيع الزبادي (الكنترول) و الزبادي المدعم بالثوفان (5\%) ثم

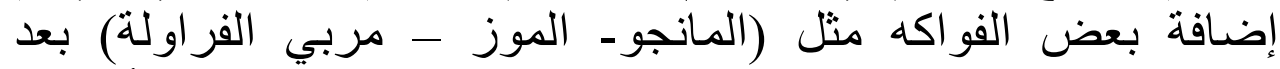

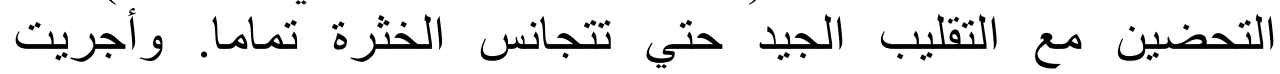

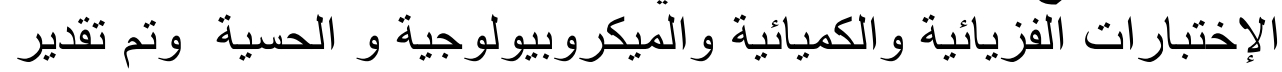

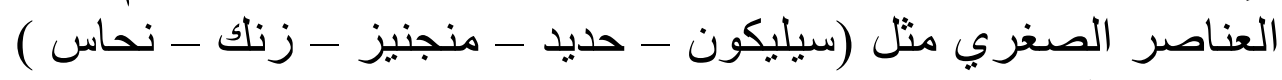

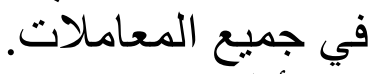

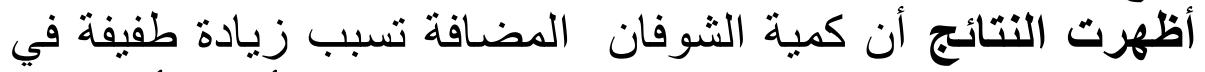

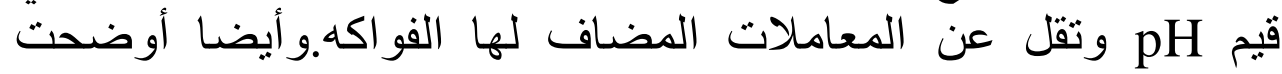

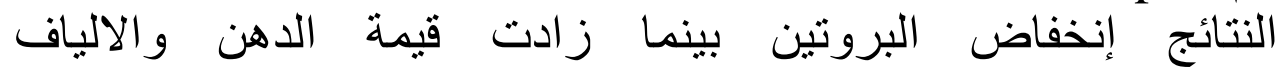

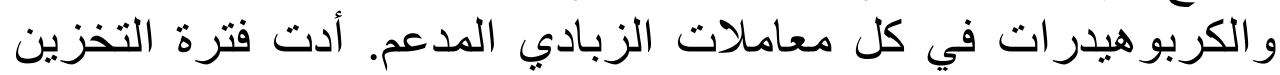

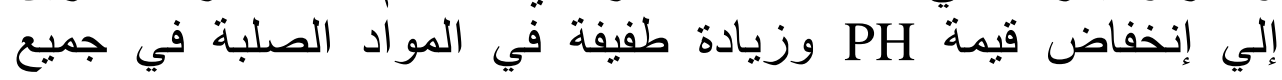

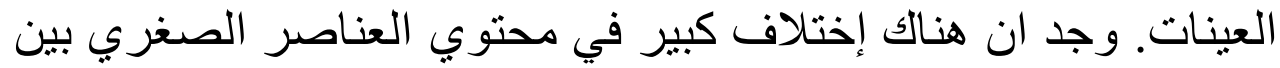

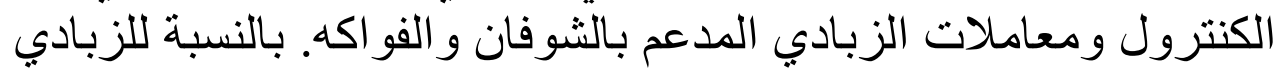


المدعم بالثوفان والفواكه فقد احتوي علي السيليكون بمقدار يتراوح

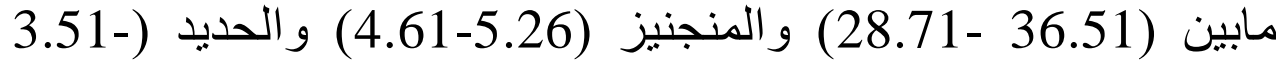

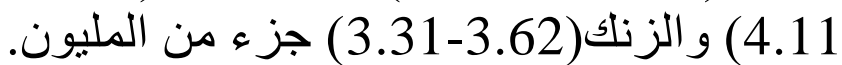

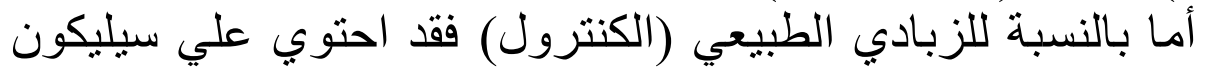

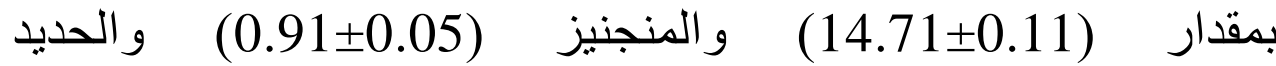

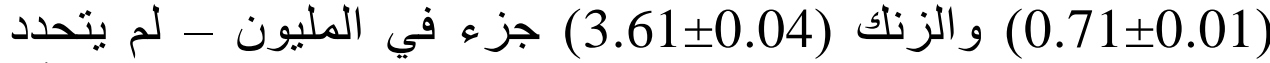

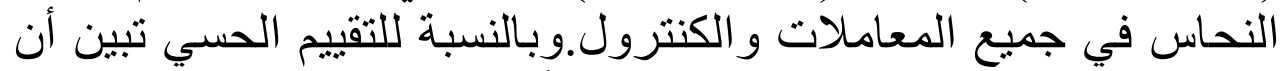

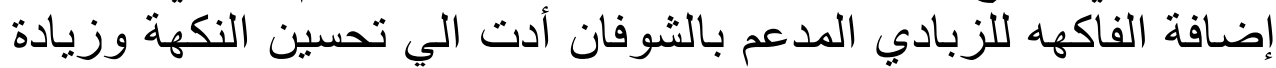
القبول العام بدرجة كبيرة. التوصية : يمكن استخدام الثوفان كمصدر بلتور طبيعي جيد في تدعيم

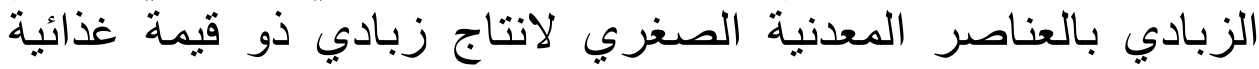
عالية. 